\title{
The detectability of shallow slow earthquakes by the Dense Oceanfloor Network system for Earthquakes and Tsunamis (DONET) in Tonankai district, Japan
}

\author{
Keisuke Ariyoshi $\cdot$ Ryoko Nakata $\cdot$ Toru Matsuzawa $\cdot$ \\ Ryota Hino · Takane Hori • Akira Hasegawa • \\ Yoshiyuki Kaneda
}

Received: 14 May 2013/Accepted: 2 September 2013/Published online: 29 September 2013

(c) The Author(s) 2013. This article is published with open access at Springerlink.com

\begin{abstract}
In order to understand the characteristics of shallow very low-frequency (VLF) events as revealed by recent ocean-floor observation studies, we perform a trial simulation of earthquake cycles in the Tonankai district by taking the characteristics of the 1944 Tonankai earthquake and assuming that slow earthquakes occur on numerous small asperities. Our simulation results show that the increase of moment release rate of shallower VLF events in the pre-seismic stage of a megathrust earthquake is higher than that of deeper VLF events. This increase may make leveling change due to VLF swarms detectable at Dense Oceanfloor Network system for Earthquakes and Tsunamis (DONET). We also introduce the time series of hydraulic pressure data at DONET, comparing with the leveling change expected from our numerical simulation. Since leveling change due to shallower VLF swarms is so local as to be incoherent, removal of the moving-averaged data from the data stacked by four nearby observation points in the same node may be useful to detect the short-term local leveling change.
\end{abstract}

Keywords Very low-frequency event · Nankai Trough $\cdot$ Leveling change $\cdot$ Earthquake cycle simulation

\footnotetext{
K. Ariyoshi $(\varangle) \cdot$ R. Nakata $\cdot$ T. Hori · Y. Kaneda Earthquake and Tsunami Research Project for Disaster Prevention, Japan Agency for Marine-Earth Science and Technology, Yokohama 236-0001, Japan e-mail: ariyoshi@jamstec.go.jp
}

T. Matsuzawa $\cdot$ R. Hino - A. Hasegawa Research Center for Prediction of Earthquakes and Volcanic Eruptions, Graduate School of Science, Tohoku University, Sendai 980-8578, Japan

R. Hino

International Research Institute of Disaster Science,

Tohoku University, Sendai 980-8579, Japan

\section{Introduction}

Following the 2004 Sumatra-Andaman Earthquake (e.g., Lay et al. 2005), the Japanese government has established the Dense Oceanfloor Network system for Earthquakes and Tsunamis (DONET) along the Nankai Trough (Fig. 1a). In the Tonankai district, $M 8$-class (M 8.1-8.5) megathrust earthquakes will probably occur in the near future (e.g., The Headquarters for Earthquake Research Promotion 2013); DONET-I has now operated since August 2011.

As an additional matter concerning the forthcoming megathrust earthquakes along the Nankai Trough, the 2011 $M_{w} 9.1$ earthquake off the Pacific coast of Tohoku (hereafter, the 2011 Tohoku earthquake) is thought to have ruptured off the coasts of Miyagi, Iwate, Fukushima, and Ibaraki, covering some tsunami source regions of large (M 7-8 class) earthquakes (e.g., Yagi and Fukahata 2011). It is possible that the 2011 Tohoku earthquake may correspond to the recurrence of the 869 Jogan earthquake (e.g., Ozawa et al. 2011), which was followed by the 887 Nin'na earthquake which gave rise to the rupturing of the source regions for both the $1946 M_{w} 8.1$ Nankai (Kanamori 1977) and $1944 M_{w} 7.9$ Tonankai (Kikuchi et al. 2003) earthquakes (Ishibashi 1999) with probably greater magnitude than the single event of either earthquake. This history of megathrust earthquakes around Japan indicates that the next megathrust earthquake in Tonankai may follow soon after the 2011 Tohoku earthquake and rupture not only Tonankai but also the Tokai and Nankai regions simultaneously with magnitude comparable to the 1707 M 8.7 Hoei earthquake (e.g., Furumura et al. 2011) in some cases.

Since DONET-I is located above the source region of the 1944 Tonankai earthquake (e.g., Kikuchi et al. 2003) as shown in Fig. 1, DONET is expected to detect the arrival of S-waves and tsunami by about several tens of seconds 
(a)

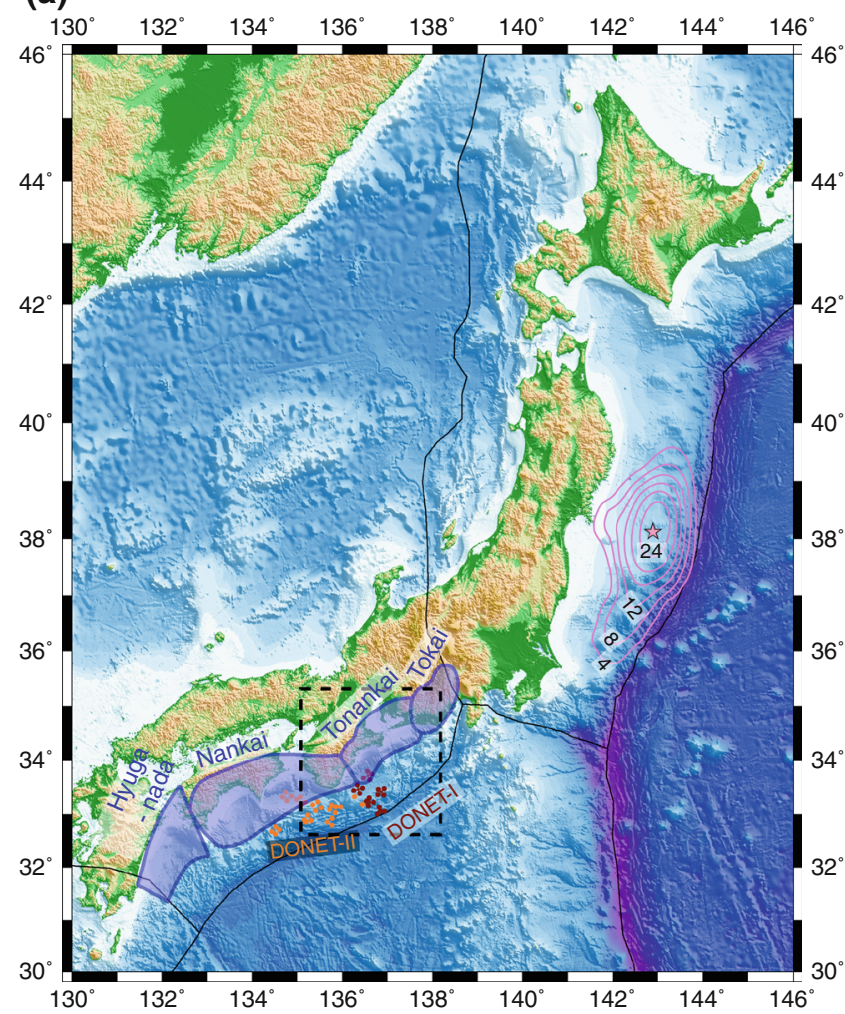

(b)

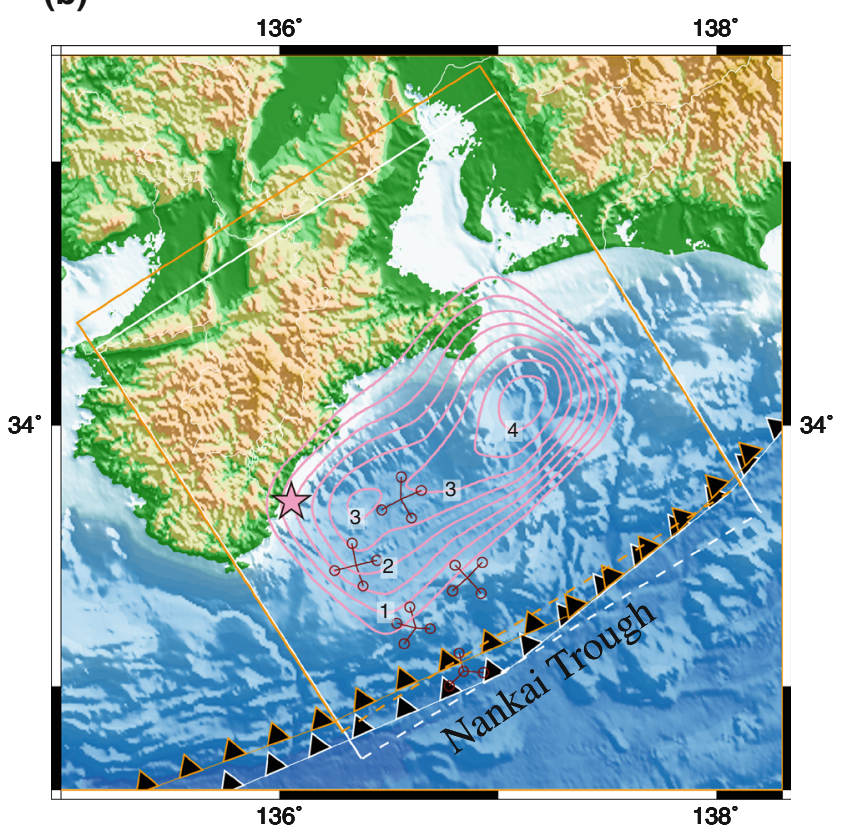

Fig. 1 a Map of Japan with observation points of DONET-I ( red $)$ and DONET-II (orange). Trench lines are based on Bird (2003). Pink star and contours show epicenter and slip isograms (with $4 \mathrm{~m}$ increment) of the 2011 Tohoku earthquake (Ozawa et al. 2011). Four blue regions along the Nankai Trough represent the estimated source regions of (in order from east to west) Tokai, Tonankai, Nankai and Hyuganada earthquakes, respectively. b Map around Tonankai district with target area of this study (rectangle with dashed line in a). Trench

and several minutes earlier than inland- and shore-observation networks, respectively (Kaneda et al. 2009). Delivering seismic and hydraulic pressure data in real time, DONET is also expected to monitor the state of parameters such as seismicity and crustal deformation around a Tonankai earthquake by responding to its pre-seismic change, as observed for the 2011 Tohoku earthquake from inland seismometers (Kato et al. 2012) and bottom-up hydrostatic pressures (Ito et al. 2013), but higher sensitivity observation near the source regions of target earthquakes has been needed. marks with orange and white colors are based on Coffin et al. (1998) and Bird (2003), respectively. Rectangles with dashed lines along the trench represent the target area of this study. Stars and contours with pink color show epicenter and slip isogram (with $0.5 \mathrm{~m}$ increment) of the 1944 Tonankai earthquake estimated by Kikuchi et al. (2003). Red circles with lines represent observation points and science nodes of DONET-I

Owing to recent campaign observations using broadband ocean-bottom seismometers near DONET-I, Sugioka et al. (2012) reported that very low-frequency (VLF) events (Ito et al. 2007) are generated by slip along the plate boundary beneath the sedimentary wedge. This means that VLF events occur in the shallow transition zone of a subduction plate boundary (Schwartz and Rokosky 2007) as well as in the deeper part (Ito et al. 2007). However, it has not yet been well established how shallower VLF events are to change in the pre-seismic stage of the forthcoming Tonankai earthquake. 
From a numerical simulation study of the deeper slow earthquakes (Ide et al. 2007), including VLF events, Ariyoshi et al. (2012) pointed out that the recurrence interval becomes shorter and the moment release rate becomes higher in the pre-seismic stage of megathrust earthquakes. As another slip event of the slow earthquake group, slowslip events (SSE) have been modeled in recent studies, which succeeded in reproducing SSE migration (Shibazaki et al. 2012) and have pointed out that the recurrence interval of SSE also becomes shorter in the pre-seismic stage of megathrust earthquakes (Matsuzawa et al. 2010). However, long-term cycle simulation of shallower slow earthquakes has not yet been modeled.

In this study, we develop the modeling of a subduction plate boundary around the source region of a Tonankai earthquake by modeling shallower slow earthquakes as well as deeper ones around a megathrust earthquake in order to understand the long-term cycle of the shallower slow earthquake from the view of detectability by DONET-I.

\section{Methods}

Owing to the recent higher performance of CPUs, the modeling of a seismic cycle on a subduction plate boundary in a uniform elastic half-space of three dimensions (3D) by applying the rate- and state-dependent friction (RSF) law (Dieterich 1979; Ruina 1983) has been successfully developed (e.g., Liu and Rice 2005; Shibazaki et al. 2012; Matsuzawa et al. 2010). Being essentially the same as previous studies, the present method of simulation is customized to fit the model of coexisting megathrust and slow earthquakes (Ariyoshi et al. 2009, 2012) on a bended plate boundary of a subduction zone (e.g., Kato and Hirasawa 1999).

Setting the subduction plate boundary model

According to the possible location of the Nankai Trough estimated by Coffin et al. (1998) and Bird (2003), we take two ways of setting a model region as shown in Fig. 1. We approximately assume that the direction of relative plate motion is in a purely dip direction at a rate of $4 \mathrm{~cm} /$ year over the whole model region. Although the observed direction of relative plate motion is different horizontally by as much as 20-30 from the dipping direction (e.g., Sella et al. 2002) and the estimated back slip rate in the corresponding region seems to be in the range of about 3-5 cm/year (Ito et al. 1999; Miyazaki and Heki 2001), we ignore these differences in the present simple modeling. Taking the result of Nakanishi et al. (2008) on the dip angle of the plate boundary, we consider a 3-D model of the Tonankai district in a uniform elastic half-space as shown in Fig. 2a, b. Because of the short length along the trench direction, we approximately assume that the shape of the subduction plate boundary is bended only along the dip direction. We also approximately assume a periodic boundary condition along the strike direction because the source region of the Tonankai earthquake is sandwiched in between Tokai and Nankai earthquakes and because VLF event migration along the strike direction straddles the Tokai and Tonankai area (e.g., Ito et al. 2007; Obara and Sekine 2009; Obara 2010). The influence of Tokai and Nankai earthquakes will be discussed in section "The case of a Tonankai earthquake triggered by Tokai/Nankai earthquakes".

Numerical simulation of the subducting plate motion

As shown by Fig. 2c, the length along the strike direction and width along the dip direction is 200 and $215 \mathrm{~km}$, respectively, which is discretized into 2,048 (strike) and 452 (dip) cells, where the cell size along the strike component is uniform $(200 \mathrm{~km} / 2,048$ cell $)$ and one along the dip component is changed on the basis of frictional stability $\left(L_{\mathrm{b}}\right)$ as described in the section "Dependency of model parameters on numerical simulation results". Slip in the target area of the plate boundary is assumed to obey the quasi-static equilibrium relationship between shear and frictional stresses,

$\mu_{i} \sigma_{i}=\sum_{j=1}^{N} K_{i j}\left(u_{j}(t)-V_{\mathrm{pl}} t\right)-\frac{G}{2 \beta} \frac{\mathrm{d} u_{i}}{\mathrm{~d} t}$,

where the subscripts $i$ and $j$ denote the location indices of a receiver and a source cell, respectively. The left-hand side of Eq. (1) describes frictional stress, where $\mu$ and $\sigma$ are the friction coefficient and effective normal stress, respectively. The right-hand side describes the shear stress in the $i$ th cell caused by dislocations, where $K_{i j}$ is the Green's function for the shear stress (Okada 1992) on the $i$ th cell, $N$ is the total number of cells, $V_{\mathrm{pl}}$ is the relative speed of the continental and oceanic plates, $t$ denotes time, $G$ is rigidity, $\beta$ is the shear wave speed. $K_{i j}$ is calculated from the quasistatic solution for uniform pure dip-slip $u$ relative to average slip $V_{\mathrm{pl}} t$ (Savage 1983) over a rectangular dislocation in the $j$ th cell. The part of the plate boundary deeper than $47 \mathrm{~km}$ is assumed to slip at the constant rate of $V_{\mathrm{pl}}$, which approximately neglects shear stress on the righthand side of Eq. (1) (Savage 1983). Parts of the first term of the right-hand side are written as convolutions under a periodic condition on the planar surface divided into an even size along the strike direction, which allows us to take advantage of a Fast Fourier Transform (FFT) convolution on the strike component and save on calculation cost (Rice 1993; Liu and Rice 2005; Ariyoshi et al. 2009). 

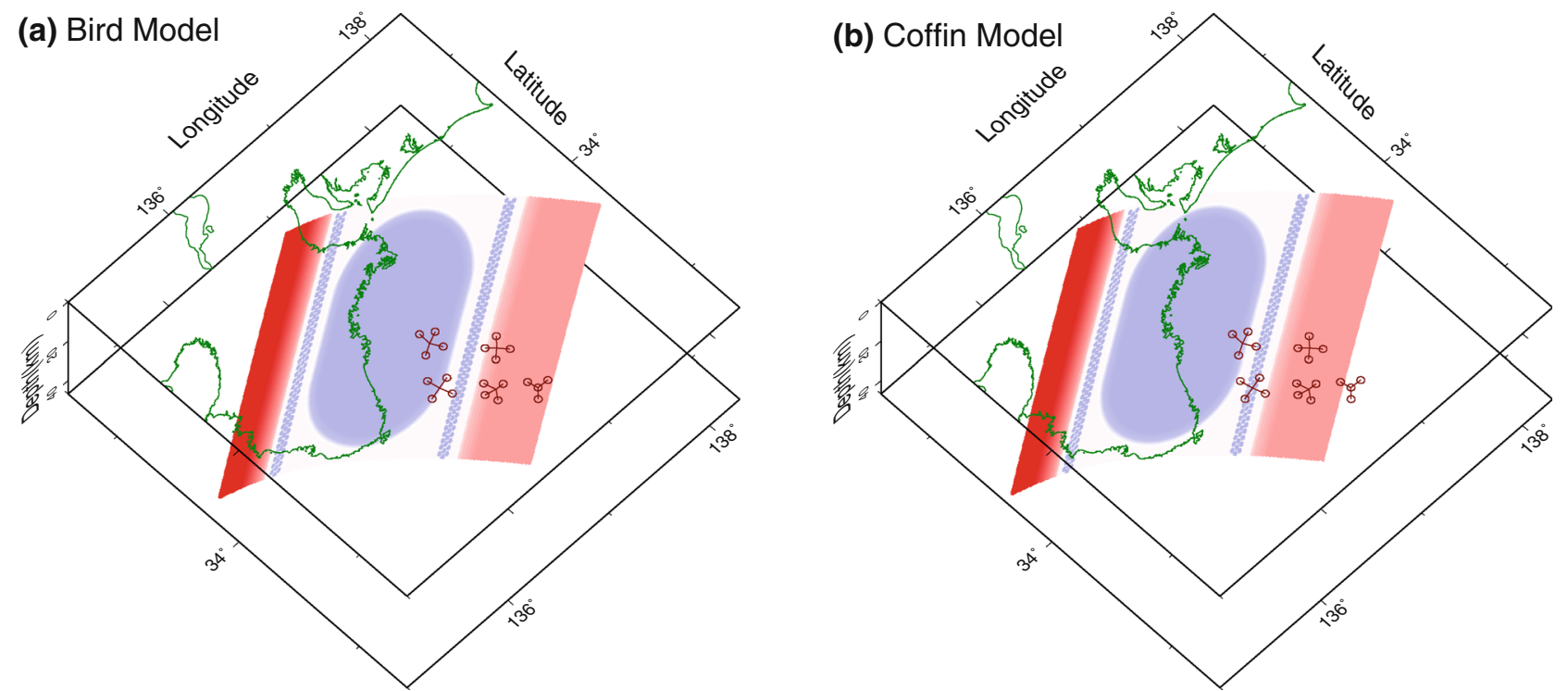

(c)

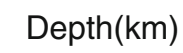

Strike $(\mathrm{km})$
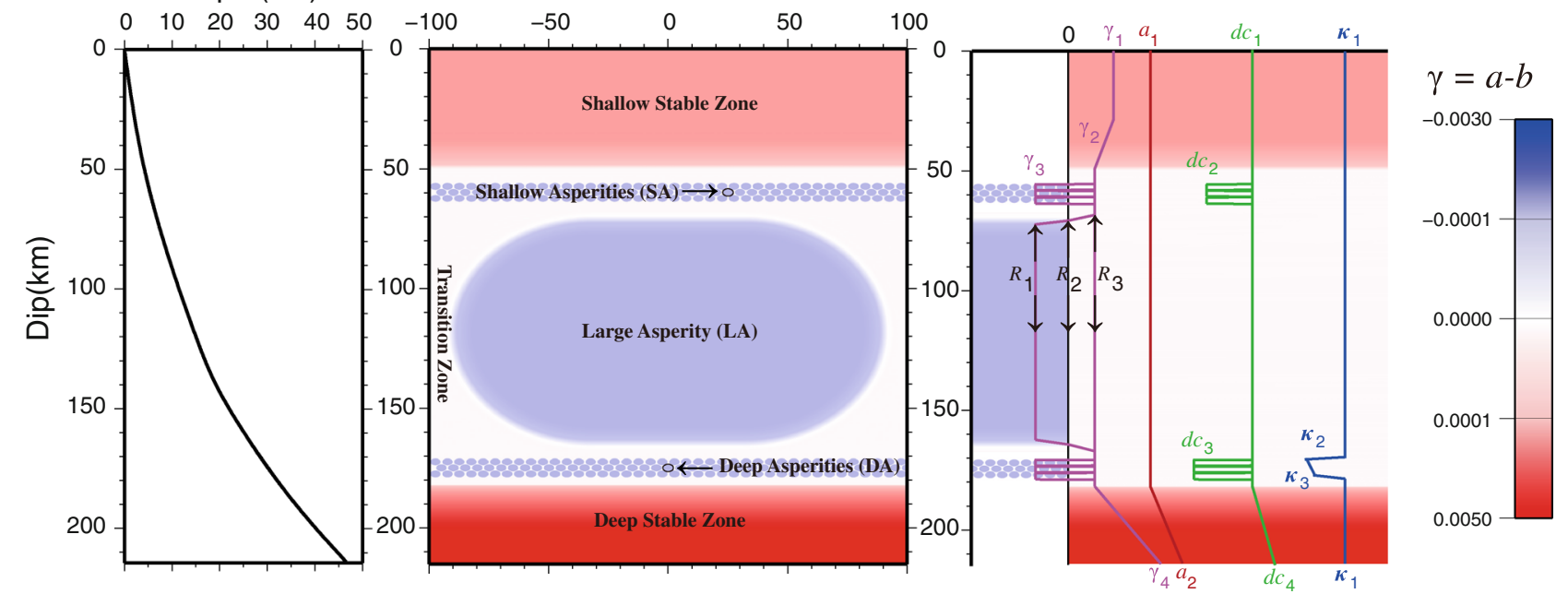

Fig. 2 a, b 3-D views of a subduction plate boundary model with frictional parameter $\gamma=a-b$ in cases of trench location based on a Bird (2003) and b Coffin et al. (1998). c Depth and frictional parameters $\left[a, \gamma, d_{c}, \kappa\right.$ (see Eq. (2)] as functions of distance along the dip direction from the surface, where $\left(a_{1}, a_{2}\right)=(2,5)\left[\times 10^{-3}\right],(\gamma 1$, $\gamma 2, \gamma 3, \gamma 4)=(0.7,0.01,-0.3,4.9)\left[\times 10^{-3}\right], \quad\left(d_{c 1}, \quad d_{c 2}, \quad d_{c 3}\right.$, $\left.d_{c 4}\right)=(10,0.3,0.4,400)[\mathrm{mm}]$, and $\left(\kappa_{1}, \kappa_{2}, \kappa_{3}\right)=(1.0,0.07$, 0.13 ). Half the length of the minor axis (along dip) of the elliptical

In Eq. (1), the effective normal stress $\sigma$ is given by,

$\sigma_{i}(z)=\kappa(z)\left(\rho_{\text {rock }}-\rho_{\mathrm{w}}\right) g z$

where $\rho_{\text {rock }}$ and $\rho_{\mathrm{w}}$ are the densities of rock and water, respectively, $g$ is the acceleration due to gravity, and $z$ is the depth. The function $\kappa(z)$ is a super-hydrostatic pore pressure factor, as given in Fig. 2c which will be discussed in section "Frictional parameters for megathrust- and slowearthquakes".

The frictional coefficient $\mu$ is assumed to obey an RSF law as given by, asperity takes the following values: for the large asperity (LA), $\left(R_{1}\right.$, $\left.R_{2}, R_{3}\right)=(30,33,35)[\mathrm{km}]$ and for shallower small asperities (SA), $\left(r_{1}, r_{2}, r_{3}\right)=(2,2.25,2.5)[\mathrm{km}]$, where the aspect ratios for LA and SA are 1.25 and 1.5 , respectively. The distance between central points of SA along strike and dip direction is 2 and $2.5 \mathrm{~km}$, respectively. The time histories for SA and deeper small asperities (DA), indicated by the arrow, are shown in Fig. 4. The values of frictional parameters are based on rock laboratory results (e.g., Blanpied et al. 1998)

$\mu=\mu_{0}+a \log \left(V / V_{0}\right)+b \log \left(V_{0} \theta / d_{c}\right)$,

$\mathrm{d} \theta / \mathrm{d} t=1-V \theta / d_{c}$,

where $a$ and $b$ are friction coefficient parameters, $d_{c}$ is the characteristic slip distance associated with $b, \theta$ is a state variable for the plate interface, $V$ is the slip velocity, and $\mu_{0}$ is a reference friction coefficient defined at a constant reference slip velocity of $V_{0}$. From several versions of RSF law, we adopt a slowness-law (Beeler et al. 1994) because of a wide range of conditions for frictional parameters occurring during slow earthquakes (Ampuero and Rubin 2008). 
Frictional parameters for megathrust- and slowearthquakes

We adopt the concept of slow earthquakes reproduced by Ariyoshi et al. (2012), which explains slow earthquake migration from the viewpoint of interaction among numerous close-set small asperities generating VLF events on the skirt of a greater asperity. In the present study, an asperity is denoted by a region with $a-b=\gamma<0$, following Boatwright and Cocco (1996). The plate interface is demarcated into six parts, as shown in Fig. 2c (1) one large asperity (LA), (2) 120 shallower (small) asperities (SA), (3) 120 deeper (small) asperities (DA) (4) a shallow stable zone, (5) a deep stable zone, and (6) a transition zone $(\gamma \sim+0)$.

To set the super-hydrostatic pore pressure factor $\kappa(z)$, we assume that a high pore pressure system exists locally around $30 \mathrm{~km}$ depth due to the dehydration derived from facies change in the slab (Kato et al. 2010) and/or permeability contrast at the Moho (Katayama et al. 2012). Ariyoshi et al. (2007a) estimated that the value of $\kappa$ is $0.1-0.5$ for the shallower part $(<30 \mathrm{~km})$ and 0.1 for the deeper part ( $>30 \mathrm{~km}$ depth) based on the post-seismic slip propagation speed. The ratio of fluid pressure to normal stress on the plate interface is estimated to be 0.94 near the fault plane of the 2011 Tohoku earthquake by inverting focal mechanisms of earthquakes (Hasegawa et al. 2011), which corresponds to $\kappa \sim 0.1$. Katayama et al. (2012) estimated the pore pressure as a function of depth. They show that pore pressure nearly reaches lithostatic pressure locally at the depth of the Moho, with a corresponding age more than $\sim 20 \mathrm{Ma}$, where the age of the Philippine Sea plate is thought to be 15-30 Ma (Müller et al. 2008).

The constant parameters in the present study are $V_{\mathrm{pl}}=$ $4.0 \times 10^{-2} \mathrm{~m} /$ year (or $1.3 \times 10^{-9} \mathrm{~m} / \mathrm{s}$ ), $\quad G=30 \mathrm{GPa}$, $\beta=3.75 \mathrm{~km} / \mathrm{s}, \quad \rho_{\text {rock }}=2.75 \times 10^{3} \mathrm{~kg} / \mathrm{m}^{3}, \quad \rho_{\mathrm{w}}=1.0 \times$ $10^{3} \mathrm{~kg} / \mathrm{m}^{3}, \quad g=9.8 \mathrm{~m} / \mathrm{s}^{2}, \quad V_{0}=1 \mu \mathrm{m} / \mathrm{s}, \quad \mu_{0}=0.6$, and Poisson's ratio $\varepsilon=0.25$.

Dependency of model parameters on numerical simulation results

All cells are smaller than the characteristic length scale $L_{\mathrm{b}}=G d_{\mathrm{c}} / \sigma b$ (Rubin and Ampuero 2005), which is related to the minimum size of nucleation zones and to the characteristic size of the process zone of propagating transients, including in the frictionally stable region $(\gamma>0)$. We check the cell size dependency by making other models with half size (twice finer) calculation cells in SA (or DA). Their characteristics of the simulation results for SA (or DA) is similar to the original model. We uniformly set the initial shear stress at the steady state friction value at a rate of $0.9 V_{\mathrm{pl}}$, where the value of initial slip velocity is independent of simulation results.

We also perform dozens of trial simulations by changing frictional parameters $\gamma\left(\gamma_{3}: 3.0\right.$ to $\left.4.8\left[\times 10^{-3}\right]\right), \kappa\left(\kappa_{2}\right.$ and $\left.\kappa_{3}: 5-15 \%\right)$ and $d_{c}\left(d_{c 2}\right.$ and $\left.d_{c 3}: 0.3-1 \mathrm{~mm}\right)$ so as to generate a megathrust earthquake on the LA and VLF events on both SA and DA, respectively, under the conditions of $L_{\mathrm{b}}$ being largely constant. The results of these simulations show qualitatively similar characteristics and will be described in the following sections.

\section{Earthquake cycle simulation results}

\section{Characteristics of megathrust earthquakes}

Our simulation results show that megathrust earthquakes occur periodically, and that the recurrence interval $\left(T_{r}\right)$ and magnitude $\left(M_{w}\right)$ are nearly constant $\left(T_{r}=113\right.$ years, $M_{w}=7.9$ ). One of the resultant spatial distributions of coseismic slip $(>3 \mathrm{~cm} / \mathrm{s})$ accompanied by a megathrust earthquake is shown in Fig. 3. The asymmetric slip distribution is due to the asymmetric distribution of SA and DA as seen in Fig. 2. The fluctuation of co-seismic slip behavior in a recurrent megathrust earthquake is so small that the locations of slip peak and the rupture initiation point can almost be considered characteristic. The small amount of slip on the edge of the southwest side is due to the periodic boundary condition along the strike component (as mentioned in section "Setting the subduction plate boundary model"), which is negligible in calculations of the seismic moment magnitude.

Compared with the co-seismic slip distribution of the 1944 Tonankai earthquake shown in Fig. 1, the simulated co-seismic slip distribution in Fig. 3 has a similar peak value ( $\sim 3.5 \mathrm{~m})$ around $(34 \mathrm{~N}, 137 \mathrm{E})$. In addition, the 1944 Tonankai earthquake has a similar magnitude $\left(M_{w} 7.9\right.$; Kikuchi et al. (2003)) and its recurrence interval is about 100-150 years (e.g., Ishibashi 1981). From these results, we consider this simulated megathrust earthquake as the likely scenario for a future Tonankai earthquake in order to investigate the characteristics of slow earthquakes for the long-term period of the megathrust earthquake cycle.

Similarities and differences between shallower and deeper slow earthquakes

Figure 4 show slip velocity normalized with respect to $V_{\mathrm{pl}}$ on a common-logarithmic scale averaged in each asperity as indicated by arrows in Fig. 2c. The origin time in Fig. 4 is set to the initiation of seismic slip on the LA. As indicated by blue lines, Fig. $4 \mathrm{a}$, b show that slip events with peak velocity higher than $V_{\mathrm{pl}}$ occur constantly for DA 
Fig. 3 Slip isograms (with $0.5 \mathrm{~m}$ increment) of the simulated Tonankai earthquake. Red star represents the epicenter of the 1944 Tonankai earthquake

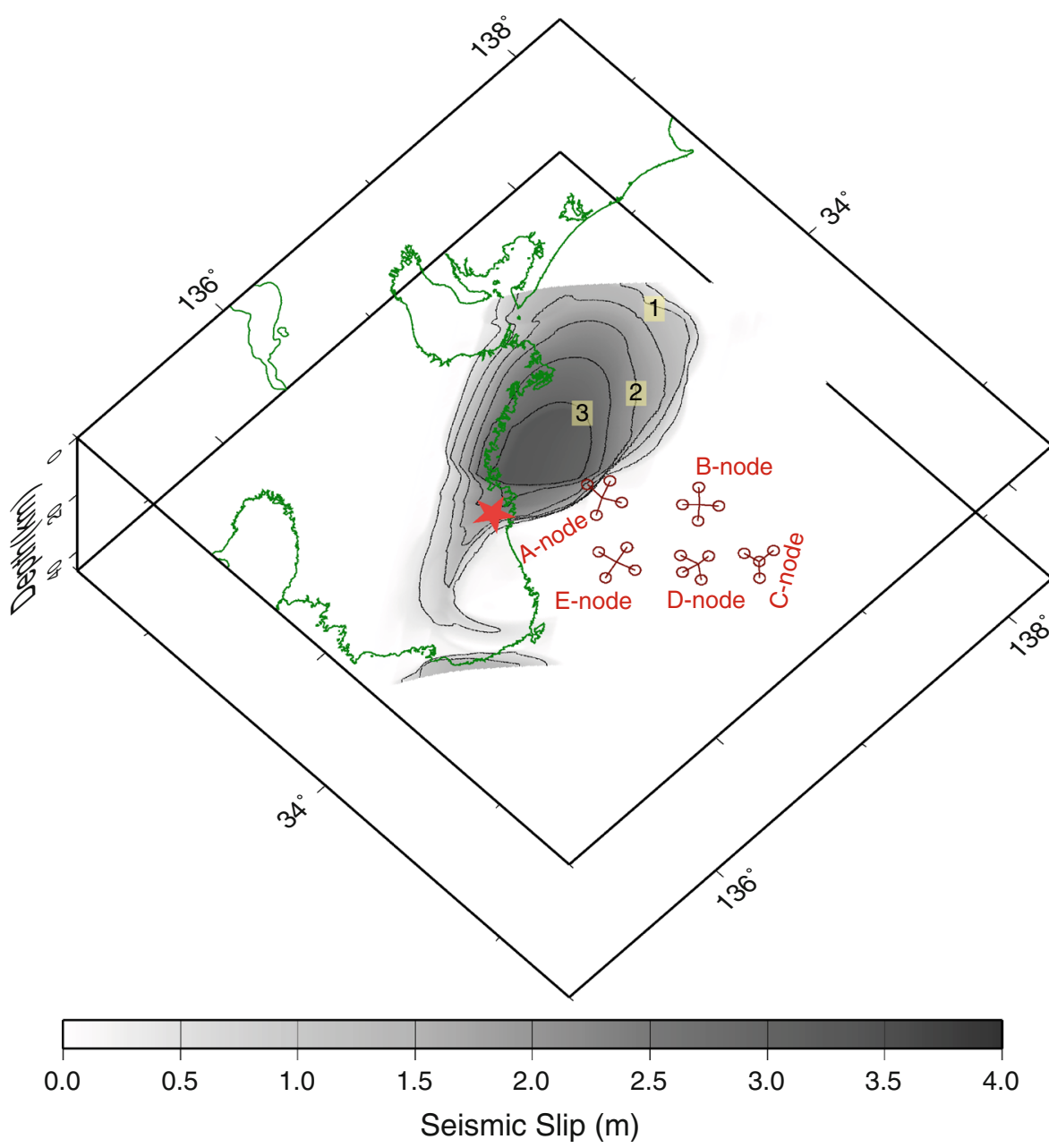

while almost temporally in the pre-seismic stage of the simulated megathrust earthquake. Figure $4 d$ shows the history of moment release rate for the slip event indicated by star in Fig. 4c focusing on 10 years before the simulated megathrust earthquake. When we assume the slip event as slow earthquake group because slow earthquake satisfies a constant moment release rate (Ando et al. 2010), we can estimate the duration time and moment release amount is $12 \mathrm{~s}$ and $7.6 \times 10^{12} \mathrm{Nm}$, respectively, which is similar relation to VLF event (Ide et al. 2007; Ariyoshi et al. 2012). About 1 year before the megathrust earthquake, however, they come to be close to regular earthquakes, including their seismic slip (faster than $3 \mathrm{~cm} / \mathrm{s}$ ), because the absolute value of moment release acceleration remains significant during slip events.

To understand the difference in slip behaviors between SA and DA, we show snapshots of slip velocity normalized by $V_{\mathrm{pl}}$ on a common-logarithmic scale on the plate boundary in the inter-seismic (Fig. 5a) and pre-seismic (Fig. 5b) stages. Figure 5a shows that a strongly sticking area $\left(\log _{10}\left(V / V_{\mathrm{pl}}\right)<-1.0\right)$ covers the center part of the SA belt, which indicates the accumulation rate of slip deficit (e.g., Ozawa et al. 2011) in the center part of SA belt is lower than that part of DA. Since higher rate of background slip velocity (warm color in Fig. 5) around asperities promotes occurring slip events more frequently (e.g., Ariyoshi et al. 2007b), the greater slip deficit against $V_{\mathrm{pl}}$ (cold color in Fig. 5) in SA prevents slip events, including VLF events, from frequently occurring and migrating along strike direction. This simulation result may explain the observational characteristics that deeper VLF events occur continuously with the migration (e.g., Obara 2010) while shallower VLF events occur sporadically without the migration (e.g., Sugioka et al. 2012). In other words, we show a new interpretation that the shallower part of the conditionally stable zone (Schwartz and Rokosky 2007) may be covered all over with small asperities along the trench direction, but shallower VLF events tend to be inactive and without migration because the stress shadow, relationship between the present observations of low seismicity rates and the occurrence of earthquakes (e.g., Maccaferri et al. 2013), is relatively stronger in the shallower part of the conditionally stable zone, especially for the center part along the strike direction $(\mid$ Strikel $<20 \mathrm{~km}$ 
Fig. 4 a, b Time histories of the common logarithm of slip velocities averaged in the areas of a shallower small asperities (SA) and $\mathbf{b}$ deeper small asperities (DA). The origin time is set to the occurrence of the simulated Tonankai earthquake. Cyan lines represent velocity at $V_{\mathrm{pl}}$ as reference. Red colored arrow represents the increase of background slip velocity in SA. c Close-up of time history in the pre-seismic stage of the

Tonankai earthquake as shown by yellow time window in a. Magenta star represents an example of slow earthquake. d Time history of the moment release rate for the slip event indicated by the magenta star in c. The origin time is set to the peak of the moment release rate. Maximum and minimum values of moment release acceleration $\left(M \mathrm{o}_{\max }\right.$ and $\left.M \mathrm{o}_{\min }\right)$ are +3.1 and $-1.2\left[\times 10^{10} \mathrm{Nm} / \mathrm{s}^{2}\right]$, respectively. Duration time $(\Delta t)$ of the slow earthquake event is $12 \mathrm{~s}$, when it is defined as $|M o(t)|<1 / 2\left|M \mathrm{o}_{\text {min }}\right|$.

Moment release amount for the duration time is $7.6\left[\times 10^{12} \mathrm{Nm}\right]$
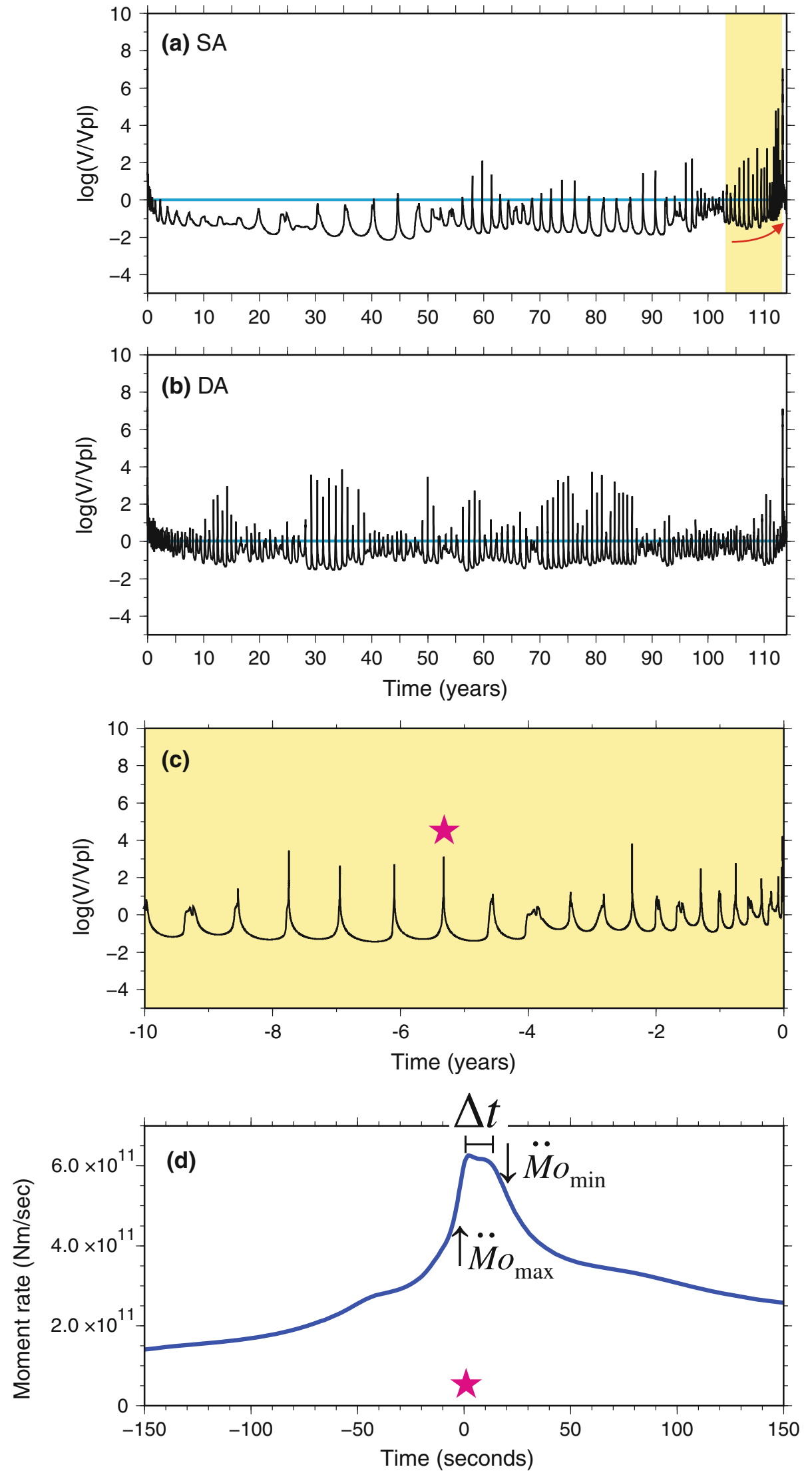
in Fig. 5). In other words, difference in slow earthquake activity between shallower and deeper part of subduction zone can be explained by the difference in stress shadow of a surrounding megathrust earthquake even if the value of frictional stability $(a-b)$ is the same between the two parts and the effect of long-term trend of $(a-b)$ due to grain size (Ikari et al. 2013) is out of consideration.

In the pre-seismic stage of the simulated megathrust earthquake, Fig. 5b shows that the strongly sticking area fades away from the SA belt due to a partial weakening of coupling around the LA. Strictly speaking, the velocity field in the SA belt appears higher than in the DA belt (indicated by the warmer color in Fig. 5b). This suggests that the stress field promoting thrust-type slip driven by the pre-seismic slip of megathrust earthquakes has a more positive effect on the SA belt than on the DA belt, which causes slow earthquakes in the SA belt and a more active and higher moment release rate than that in the DA belt as shown in Fig. 4. That is, the SA belt near the free surface is more sensitive to the stress field caused by slip around the LA belt than the DA belt.

\section{Crustal deformation due to shallower slow earthquake swarms}

Around the source region of the simulated Tonankai earthquake, if shallower slow earthquakes occur in the belt of small asperities along a depth of about $5 \mathrm{~km}$, DONET-I is expected to respond significantly to the slow earthquakes because of the short distance between the source of VLF events and observation points, as shown in Fig. 2a, b. We analytically estimate the leveling change at DONET-I observation points by

$H_{k}=\sum_{j=1}^{N} L_{k j} u_{j}(t)$,

where $H$ is the amount of leveling change, $L$ is Green's function for the leveling change due to dip slip in $j$ th source cell (Okada 1992) on the $k$ th DONET-I observation point depending on Coffin or Bird Model as shown in Fig. 2a, b. Note that the product of $L_{\mathrm{kj}} u_{j}(t)$ is significant only in the source regions of shallower slow earthquakes in the preseismic stage of LA.

Figure 6 shows the leveling change at DONET-I observation points in the case of the Bird and Coffin models (Fig. 2a, b, respectively) from 10 years before to the onset of the simulated Tonankai earthquake. In Fig. 6, long-term uplift is derived from the pre-seismic slip of the Tonankai earthquake, while short-term uplift/depression is from shallower slow earthquakes. In this section, we investigate the characteristics of each crustal deformation.
Long-term crustal deformation

Figure 6 shows the difference between science nodes (A-E in Fig. 1b); long-term (longer than several years) leveling change and temporal acceleration of the uplift at nodes closer to the LA (e.g., A- and E-nodes) is greater than that at nodes closer to the trench (e.g., $\mathrm{C}$-node) mainly because of the shorter distance from LA where pre-seismic slip occurs around there as shown in Fig. 5b.

The node closer to the LA shows greater difference among leveling observation points in the same node (e.g., difference between E-18 and E-20 in Fig. 1b) than that closer to trench (e.g., C-9 and C-12), which is more significant after the time indicated by broken lines in Fig. 6 . This is because the difference of distance from LA to leveling observation points in the same node closer to the trench (e.g., differential of distance between $<$ C-9 to LA $>$ and $<\mathrm{C}-12$ to $\mathrm{LA}>$ ) is relatively smaller than that in a node closer to the LA (e.g., differential between $<$ E-18 to LA $>$ and $<$ E-20 to $\mathrm{LA}>$ ).

In Fig. 5, the gray-colored DONET-I array shows the crustal deformation of the horizontal component magnified 50,000 times for 2.5 years in the inter-seismic (Fig. 5a; almost overlapped with red-colored DONET-I array) and pre-seismic (Fig. 5b) stages of the simulated Tonankai earthquake. From Fig. 5, we find that the horizontal deformation at DONET-I appears too small to be detected for all nodes in the inter-seismic stage of the simulated Tonankai earthquake (Fig. 5a), but is significantly greater for all nodes in the pre-seismic stage. In addition, the difference of horizontal deformation among observation points in the same node for the node closer to the LA (e.g., the difference of horizontal deformation between E-18 and E-20) tends to be greater than that for the node closer to the trench (e.g., the difference between C-9 and C-12), which is similar to the characteristics of leveling change as mentioned above in the pre-seismic stage. These results suggest that seafloor geodetic measurements using the GPS/acoustic technique (e.g., Kido et al. 2006) with electric power supply from DONET may be helpful in continuously monitoring long-term crustal deformation due to pre-seismic slip of a future Tonankai earthquake.

These characteristics are common to both Coffin and Bird models. Since the Bird model has a shorter distance from the LA to the observational points than the Coffin model, crustal deformation in the Bird model tends to be greater than in the Coffin model. This result suggests that precise determination of the subduction plate structure plays an important role on quantitatively evaluating the crustal deformation on the ocean-floor observation points. 
Fig. 5 a 3-D view of the slip velocity field on the subduction plate boundary in the case of the Bird (2003) model. Red circles and lines represent observation points and science nodes of DONET-I. Gray circles represent crustal deformation of the horizontal component magnified 50,000 times for 2.5 years from 20 years after (Fig. 5a) and 10 years before (Fig. 5b) the onset of the simulated Tonankai earthquake. Note that gray colored DONETI in Fig. 5a is almost overlapped with red colored one because of too small crustal deformation
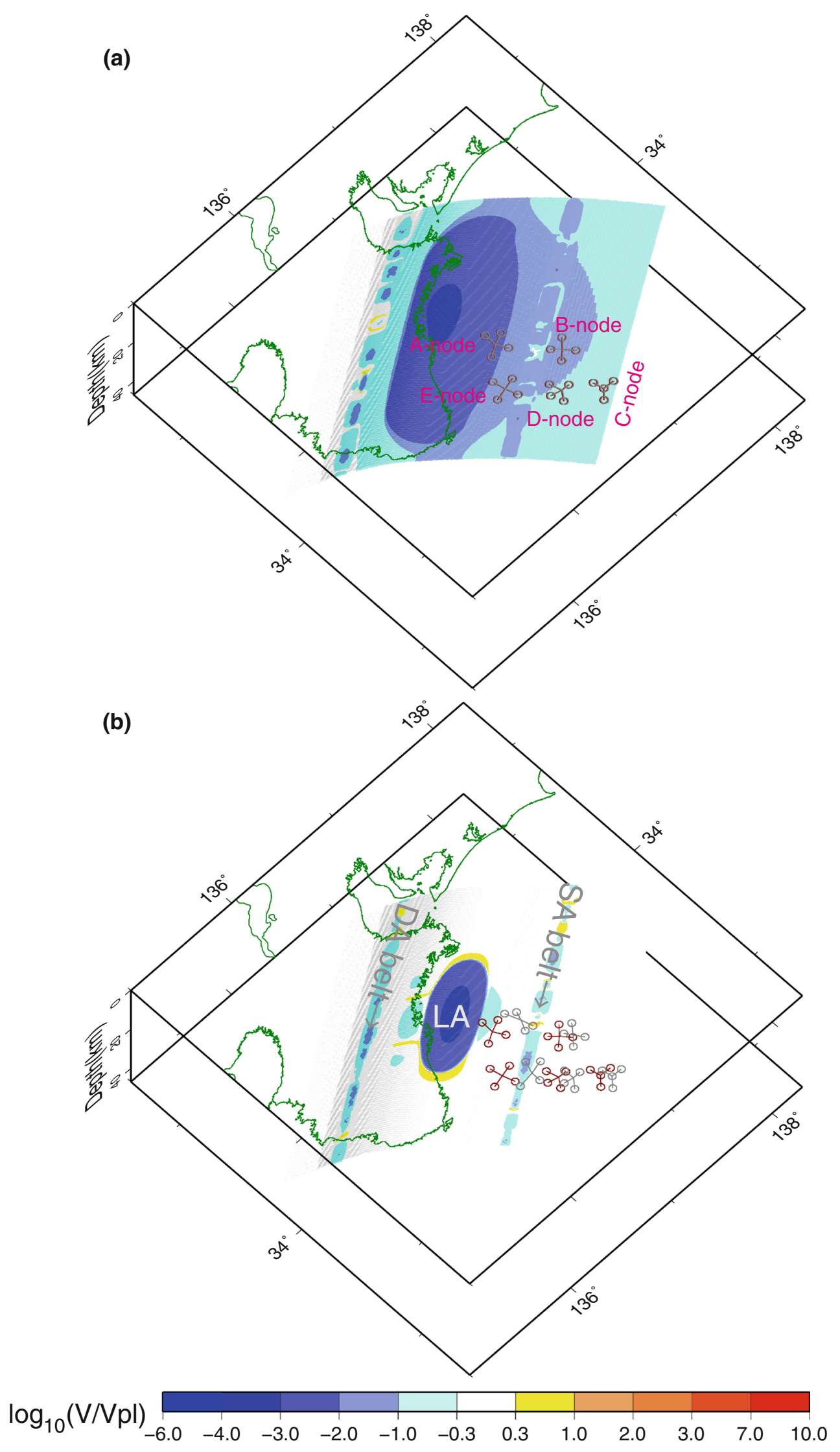
Fig. 6 Leveling change at DONET-I from 10 years before the onset of the simlulated Tonankai earthquake in case of (a) the Coffin et al. (1998) and (b) Bird (2003) models. Green colored time windows for E-node are shown in Fig. 7. Dark green colored curves are 4 times close-up of the time history in the green colored time windows. Two red lines represent the rate of 10 and $100 \mathrm{~Pa} /$ year
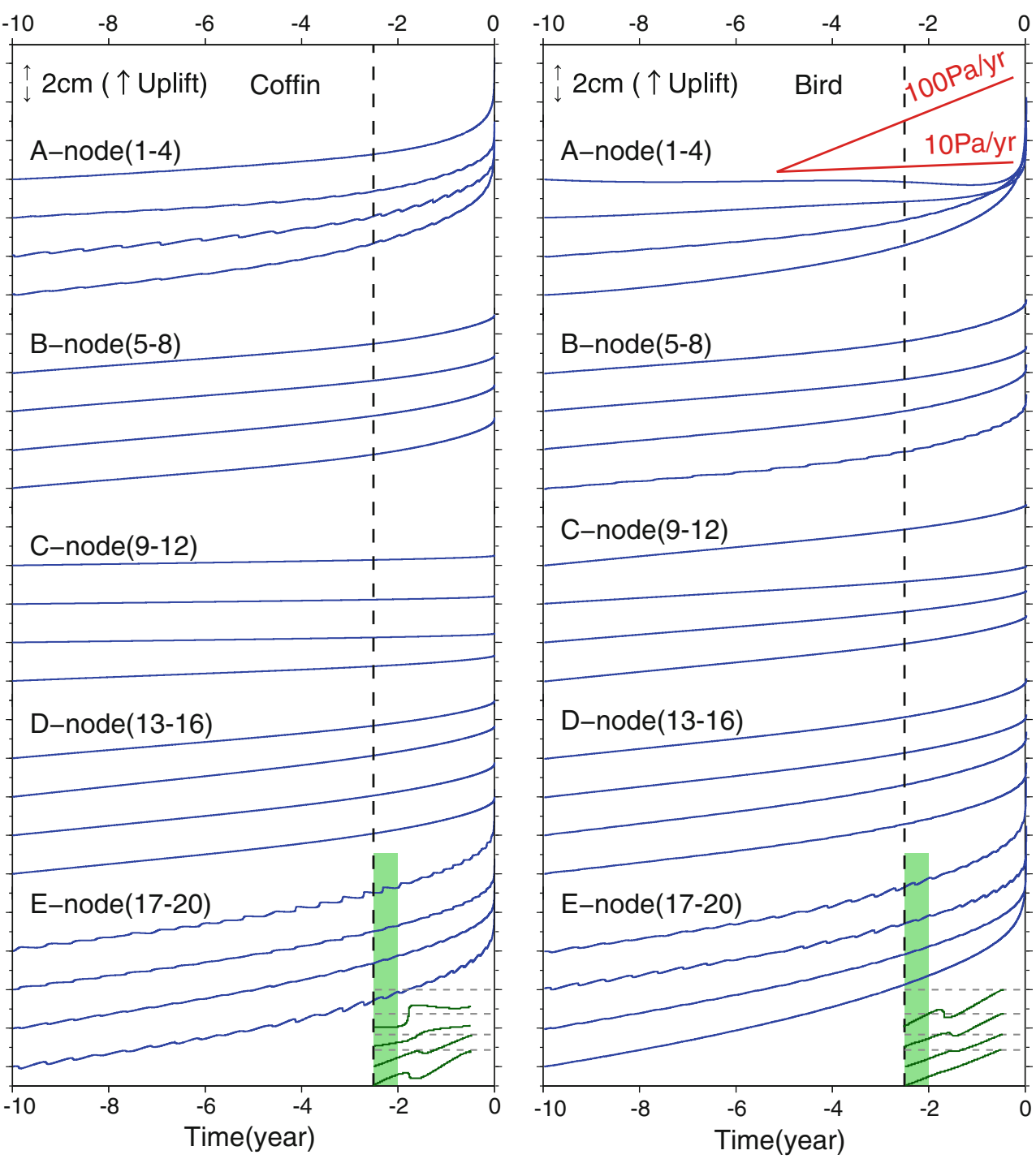

Short-term leveling change accompanied by slow earthquake swarms

For E-node, Fig. 6 shows short-term (shorter than several days) leveling change due to slow earthquake swarms appears significantly for both Coffin and Bird models. However, its characteristics are different between the two models. In B-node, short-term leveling change appears significantly only for the Bird model (B-8), while it only appears in A-node (A-2, A-3 and A-4) for the Coffin model. These results mean that the crustal deformation is so localized because of the short distance between the sources of the slow earthquake swarms and the receivers of DONET-I, which requires a denser network around the epicenters of shallower slow earthquakes when we detect them by stacking data of the short-term leveling change.

On the points of E-17 and E-18, the short-term leveling change is uplift for the Coffin model while depression for the
Bird model. These differences can be generally explained on the basis of dislocation theory in case of dip slip on a buried fault (e.g., Segall 2010), where vertical displacement on the free surface is uplift with relatively steep slope around the updip edge of a fault and depression with relatively slight slope around the downdip edge of a fault. In case of the Coffin model as shown in Fig. 2b, E-17 and E-18 are located on the updip part of SA while E-19 and E-20 (but no significant change because of too far from the SA belt) on the downdip part of SA belt, while all of observation points for E-node are on the downdip part in case of the Bird model as shown in Fig. 2a, which is consistent with the theoretical analysis.

Therefore, precise determination of slow earthquake hypocenters and trench location is very important to estimate the short-term leveling change at DONET in advance from numerical simulations.

For nodes responding significantly to slow earthquake swarms in Fig. 6, the rate of leveling change tends to be 
higher toward the origin of the simulated Tonankai earthquake. In the pre-seismic stage of a megathrust earthquake, the moment release rate of slow earthquakes, which is expected to be proportional to slip velocity averaged in SA or DA under the condition of fixed fault area, becomes higher as shown in Fig. 4a due to pre-seismic slip around the LA (Ariyoshi et al. 2012), which explains the higher rate of leveling change. The ability of DONET to detect the short-term leveling change in the pre-seismic stage of a future Tonankai earthquake will be discussed in the next section.

\section{Discussion}

Detectability of shallower slow earthquakes by DONET

In order to detect leveling change by hydraulic pressure gauges, it is necessary to remove noise and drift components from raw data. From previous long-term seafloor measurements of Paroscientific pressure gauge (e.g.,
Polster et al. 2009) which is used for DONET, the estimated noise level is about $10-20 \mathrm{~Pa}$, and drift rate is about $5-10 \mathrm{kPa} /$ year with a time constant of about 50-200 days. Figure 6 illustrates the long-term leveling change at DONET-I; the rate of the long-term leveling change is shown to be about 10 (C-node)-100 (A, E-nodes) Pa/year, which is lower than the estimated drift component. Figure 6 also shows the time constant of long-term leveling change is significantly longer than 1 year. These results mean that we can estimate the drift component by subtracting crustal deformation calculated in Fig. 6 if our simulation results can reproduce pre-seismic slip quantitatively, while it may be difficult for us to extract the longterm crustal deformation from hydraulic pressure gauge data at a single point of DONET-I if our simulation results explain crustal deformation just qualitatively. Since the trend of long-term change in all nodes is uplift, stacking data in the same node and/or combination of several nodes, which should be removed the sensor drift and noise components individually for each hydraulic pressure gauge, may be helpful to detect the long-term crustal deformation.
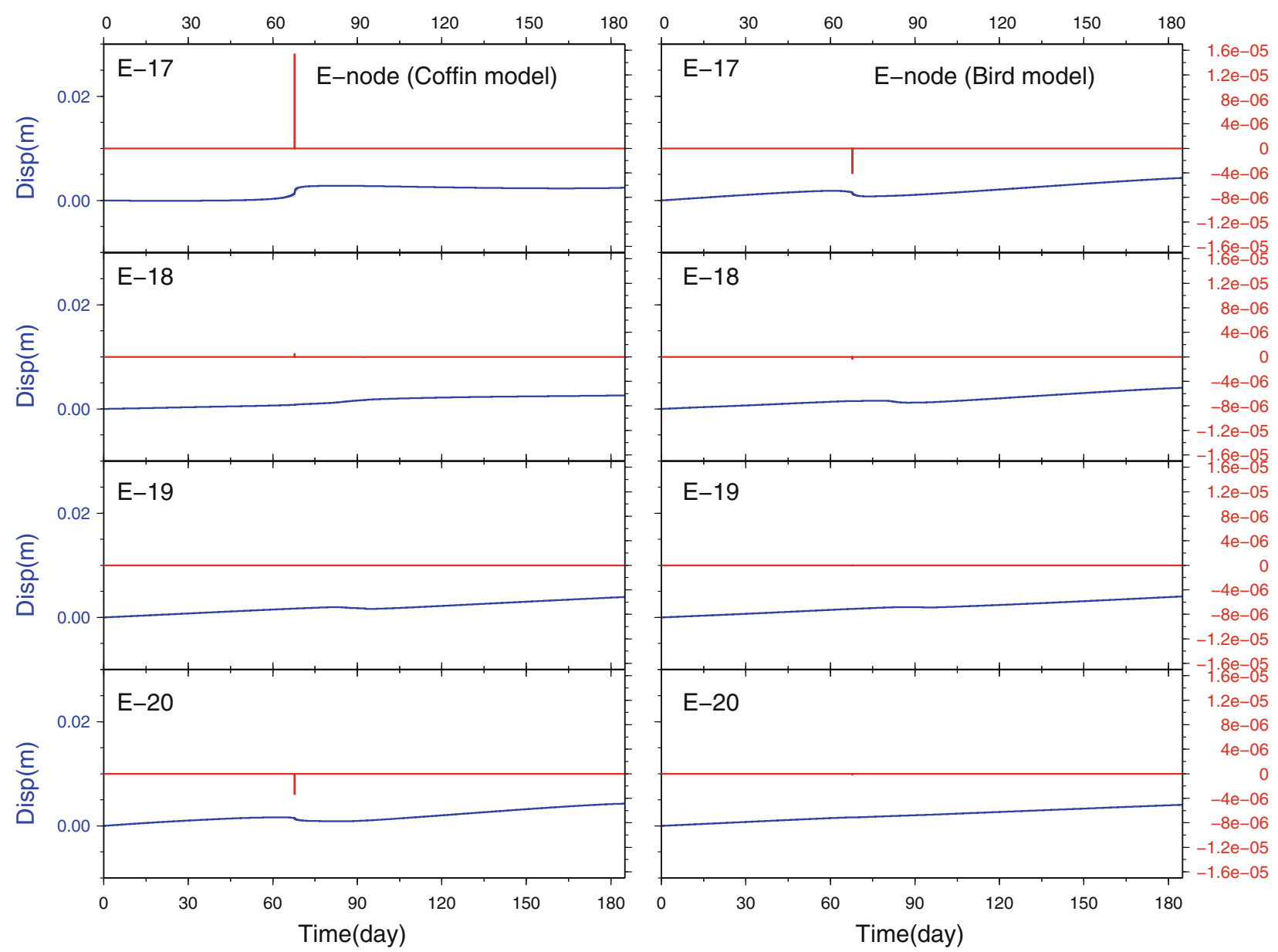

Fig. 7 Leveling changes (blue lines) and their rates (red lines) at E-node of DONET-I for about half a year as a close-up of the green colored time windows in Fig. 7, origin time is set to the start time of the green windows 

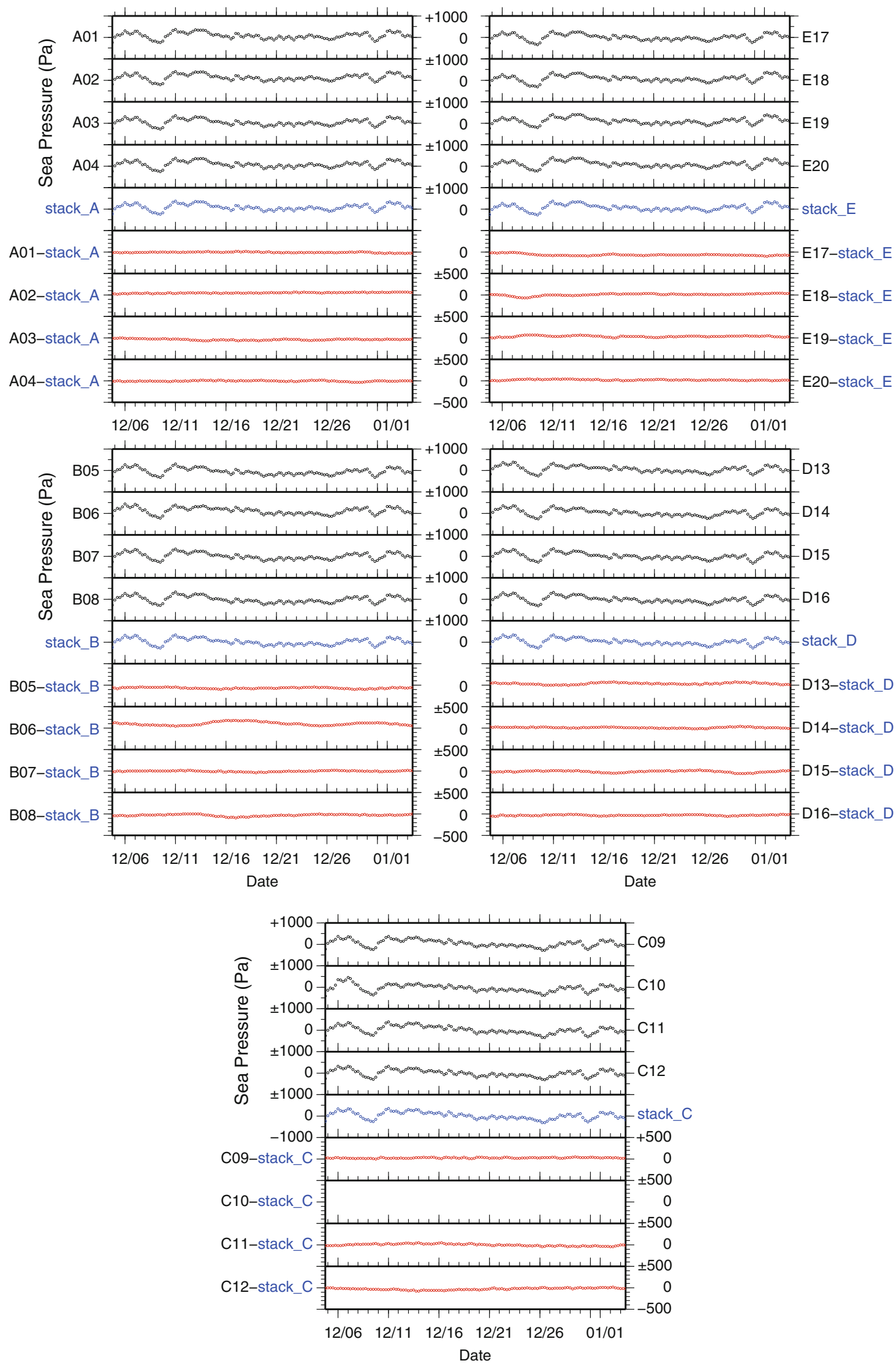
4 Fig. 8 Daily analyzed data from hydraulic pressure gauge observed at DONET-I for 1 month. Time series plotted by black (upper four columns), blue (middle column) and red (lower four columns) circles represents filtered data (moving average of $100 \mathrm{~Hz}$ data at intervals of $6 \mathrm{~h}$ in a time window of $12 \mathrm{~h}$ ), stack data (average of the filtered data in the same node), and differential data (removal of the filtered data from the stack data), respectively

Figure 7 illustrates the short-term leveling change due to slow earthquake swarms, and shows a close-up of leveling change for E-node from 2.5 to 2.0 years before the onset of the simulated Tonankai earthquake. Focusing on E-17, our simulation result shows the maximum rate of leveling change is about $1.5 \times 10^{-5} \mathrm{~m} / \mathrm{s}\left(4.4 \times 10^{+3} \mathrm{kPa} /\right.$ year $)$ with a duration time of about $0.74 \mathrm{~s}$, which is sufficiently higher rate and with shorter duration than the estimated drift component (Polster et al. 2009) as described above. However, the amount of the short-term leveling change at E-17 is expected to be about $2 \mathrm{~mm}(20 \mathrm{~Pa})$, which suggests that the short-term leveling change could be obscured by the noise component. This small leveling change driven by shallower VLF swarms is due to a low dip angle (about $5^{\circ}$ on SA from Fig. 2c) in our model.

Toward real-time monitoring of crustal deformation near the trench before the occurrence of the next Tonankai earthquake in the near future, it is desirable to deal with DONET data simply rather than detail analysis of long-term measurements. Figure 8 shows a test sample of daily processed data at DONET-I for 1 month, whose data processing interval will be much shorter than 1 day when we use the processed data for real-time monitoring. In this test, we calculate a moving average of $100 \mathrm{~Hz}$ data de-tided by using the code of Tide $4 \mathrm{n}$ (Tamura et al. 1991) at intervals of $6 \mathrm{~h}$ in a time window of $12 \mathrm{~h}$ (hereafter, referred to as filtered data). Next, we get stack data by averaging the filtered data at four points in the same node. The stack data is used to reduce electromagnetic noise and amplify systematic response to the change of sea temperature and ocean flow in addition to long-term leveling change due to large pre-seismic slip around LA. The stack data is more robust to treat as reference rather than single filtered data at a nearby observation point because of short range among four observation points in the same node. Then, we make a differential component (hereafter, referred to as differential data) by removing the stack data from the filtered data. The differential data is used to extract local crustal deformation such as slow earthquake swarms as shown for E-node in Fig. 6 and relative long-term leveling change which is significantly seen for A-node of the Bird model in Fig. 6. Since both the stack and differential data is updated from new sampling one by one, we can carry out these processes in real-time.

Focusing on the differential data in Fig. 8, we find that its fluctuation is about several tens of $\mathrm{Pa}$ (several millimeters for leveling change), which is comparable to the leveling amount of short-term change as shown at E-17 of the Coffin model in Fig. 7 (about $2 \mathrm{~mm}$ : $20 \mathrm{~Pa}$ ). From Fig. 7, we see that the short-term leveling change is incoherent in the same node. Supposing that a hydraulic pressure gauge responding to shallower VLF swarms at only one observation point in a node as seen for E-17 of the Coffin model in Fig. 7 for simplicity, the differential data is expected to contain three quarters of its value $(15 \mathrm{~Pa}$ in case of $20 \mathrm{~Pa}$ at E-17 in Fig. 7 when the change at E-20 is negligible). This estimation suggests that short-term local leveling change driven by shallower VLF swarms might be buried by the fluctuation in the case of using only hydraulic pressure gauges.

As shown in Fig. 8, we now have a continued daily solution of hydraulic pressure gauge data as a simple test run by using a moving average from $100 \mathrm{~Hz}$ sampling data in a $6 \mathrm{~h}$ time-interval. Since some VLF events may have a duration time shorter than $1 \mathrm{~s}$ as shown at E-17 in Fig. 7, in the future we have to enhance the sampling of the differential data from daily to higher than $1 \mathrm{~Hz}$ to detect the temporal and local leveling change due to shallower VLF swarms. In the hydraulic pressure gauges of DONET, water temperature gauges are also installed, which helps us to reduce the noise component in both the stack and differential data by temperature correction (Inazu and Hino 2011).

DONET has broad-band seismometers buried in the ocean floor at nearly the same location as the hydraulic pressure gauges (Nakano et al. 2013a, b), which enable us to estimate the fault parameters of shallow VLF events. Since the dip angle of the basal plane of the overriding wedge (décollement) is steeper than that of oceanic plate near the trench (e.g., Ikari and Saffer 2012), shallow VLF events on a décollement (Sugioka et al. 2012) or on megasplay faults (Ito and Obara 2006) are expected to cause a leveling change higher than our simulation results (Fig. 7) in the case of a dip angle of a VLF event significantly steeper than $5^{\circ}$. When we also use the origin time and hypocenter location of a VLF event automatically detected by seismometers, the accuracy of detecting VLF events on the basis of leveling change of DONET is expected to become higher.

The case of a Tonankai earthquake triggered by Tokai/ Nankai earthquakes

As mentioned in section "Setting the subduction plate boundary model", we adopt a periodic boundary condition along the strike direction to take nearby megathrust earthquakes and slow earthquake migration in the Tokai and Nankai regions into account. This condition means that a Tokai and Nankai earthquake occurs simultaneously with a Tonankai earthquake. However, the actual earthquake 
generation cycle along the Nankai-Suruga trough is thought to be complicated. There are numerous examples of this complicated generation cycle (e.g., Ishibashi 1981). The 1096 Eicho earthquake is thought to have ruptured at least the Tonankai area and possibly the western part of the Tokai area, which was followed by the 1099 Kowa earthquake rupturing the Nankai area. The 1498 Meio earthquake is thought to have ruptured at least the Tokai and Tonankai areas and possibly the eastern part of the Nankai area. The 1707 Hoei earthquake is thought to have ruptured almost the whole extent of the source segments including the Tokai, Tonankai and Nankai areas. The 1854 Ansei earthquake is thought to have simultaneously ruptured the Tokai and Tonankai areas, then the Nankai area $30 \mathrm{~h}$ after. The 1946 Nankai earthquake occurred 2 years after the 1944 Tonankai earthquake. As mentioned above, those previous studies (e.g., Ishibashi 1981) on these historical earthquakes along the Nankai Trough suggest that the Tonankai earthquakes have occurred with a time-lag between a Tokai or Nankai earthquake or almost simultaneously. In this section, we discuss the case of a Tonankai earthquake triggered by Tokai and Nankai earthquakes.

From numerical simulations of earthquake cycles on a subduction plate boundary, the propagation speed of postseismic slip is higher in the shallower part when effective normal stress is proportional to the depth (Ariyoshi et al. $2007 \mathrm{a}, \mathrm{b}$ ). Applying this simulation result to historical earthquakes along the Nankai Trough, we interpret that the rupture initiation of the 1946 Nankai earthquake was located on the southeastern edge of the source region (e.g., Kanamori 1972) and was triggered by post-seismic slip of the 1944 Tokai earthquake propagating westward from the shallower part of the subduction plate boundary. In another numerical simulation similarly based on RSF law, Hyodo and Hori (2010) reproduced a complex cycle of Nankai earthquakes following the Tonankai earthquakes 4.9-457 days after, where all of the rupture initiations were from a similar location to the 1946 Nankai earthquake. This means that the 1854 Ansei earthquake may also have ruptured from the southeastern edge of the Nankai area. From these results, if the next Tonankai (or Nankai) earthquake is triggered by a Nankai (or Tonankai) earthquake, the post-seismic slip of the preceding megathrust earthquake will propagate in the shallower part of the transition zone between Tonankai and Nankai earthquakes.

Compared with a single event, slip amount in a seismogenic segment increases in each of the co-, pre- and postseismic stages when an earthquake occurs shortly after another earthquake in a nearby seismogenic segment (Ariyoshi et al. 2009). This means that Nankai earthquakes following Tonankai earthquakes with a short time delay have pre-seismic slip greater than that that of a single event. Since DONET-I and DONET-II are located on the southwestern part of the simulated Tonankai earthquake and near the southeastern edge of the Nankai earthquake zones, crustal deformation, including leveling change due to pre-seismic slip, may become detectable in the case of there being a short time delay from the initiation of a nearby megathrust earthquake.

In this study, taking advantage of an FFT algorithm, we assume a subduction plate boundary bended only along the dip direction (2.5-Dimension) so as to perform multi-scale (LA and SA) earthquake cycle simulation by discretizing at most about one million calculation cells, which is very difficult for a 3-D subduction plate boundary model (e.g., Hyodo and Hori 2010) because of the huge calculation cost without using FFT. Since crustal deformation at DONET is sensitive to the shape and location of the subduction plate boundary, it is a our future study aim to develop a largescale numerical simulation of megathrust- and slowearthquake cycles on a 3-D subduction plate boundary based on structural surveys (e.g., Nakanishi et al. 2008).

\section{Conclusions}

Our results are summarized as follows.

1. Since leveling change due to slow earthquakes at DONET is expected to be local and incoherent in the same node because of the short distance between their sources and the (DONET) receiver, it is useful to remove an average from original data in the same node in order to extract a signal.

2. In the pre-seismic stage of megathrust earthquakes, the crustal deformation rate driven by slow earthquakes tends to become higher, which is greater for the shallower VLF events than that for deeper ones. This means that a combination of seismometers to decide origin time and hydraulic pressure gauges to estimate leveling change may be a helpful tool to robustly detect crustal deformation.

3. If the next Nankai/Tonankai earthquake also follows the nearby Tonankai/Nankai earthquake with a short time delay such as the 1854 Ansei earthquake, the detectable crustal deformation at DONET is expected to become more predominant due to larger pre-seismic slip of the Nankai/Tonankai earthquake. This temporal change would help us to judge the possibility of triggering nearby megathrust earthquakes in advance.

Acknowledgments The authors would like to thank H. Matsumoto for discussion about the evaluation of the noise component in hydraulic pressure. Two anonymous reviewers helped us to improve the manuscript in a better readable way. The present study used the Earth Simulator and the supercomputing resources at the Cyberscience Center of Tohoku University. GMT software (Wessel and 
Smith 1998) was used to draw a number of the figures. Hydraulic pressure data shown in Fig. 8 was conducted by the DONET program of the Ministry of Education, Culture, Sports, Science and Technology (MEXT). This study was partly supported by MEXT for Young Scientists (B), 23710212, 2013 and for Geofluids program.

Open Access This article is distributed under the terms of the Creative Commons Attribution License which permits any use, distribution, and reproduction in any medium, provided the original author(s) and the source are credited.

\section{References}

Ampuero JP, Rubin AM (2008) Earthquake nucleation on rate state faults-aging and slip laws. J Geophys Res 113:B01302. doi:10. 1029/2007JB005082

Ando R, Nakata R, Hori T (2010) A slip pulse model with fault heterogeneity for low-frequency earthquakes and tremor along plate interfaces. Geophys Res Lett 37:L10310. doi:10.1029/ 2010GL043056

Ariyoshi K, Matsuzawa T, Hasegawa A (2007a) The key frictional parameters controlling spatial variations in the speed of postseismic-slip propagation on a subduction plate boundary. Earth Planet Sci Lett 256:136-146. doi:10.1016/j.eps1.2007.01.019

Ariyoshi K, Matsuzawa T, Hino R, Hasegawa A (2007b) Triggered non-similar slip events on repeating earthquake asperities: results from 3D numerical simulations based on a friction law. Geophys Res Lett 34:L02308. doi:10.1029/2006GL028323

Ariyoshi K, Hori T, Ampuero JP, Kaneda Y, Matsuzawa T, Hino R, Hasegawa A (2009) Influence of interaction between small asperities on various types of slow earthquakes in a 3-D simulation for a subduction plate boundary. Gondwana Res 16(3-4):534-544. doi:10.1016/j.gr.2009.03.006

Ariyoshi K, Matsuzawa T, Ampuero JP, Nakata R, Hori T, Kaneda Y, Hasegawa A (2012) Migration process of very low-frequency events based on a chain-reaction model and its application to the detection of preseismic slip for megathrust earthquakes. Earth Planets Space 64(8):693-702. doi:10.5047/eps.2010.09.003

Beeler NM, Tullis TE, Weeks JD (1994) The roles of time and displacement in the evolution effect in rock friction. Geophys Res Lett 21:1987-1990

Bird P (2003) An updated digital model of plate boundaries. Geochem Geophys Geosyst 4(3):1027. doi:10.1029/2001GC000252

Blanpied ML, Marone CJ, Lockner DA, Byerlee JD, King DP (1998) Quantitative measure of the variation in fault rheology due to fluid-rock interactions. J Geophys Res 103:9691-9712

Boatwright J, Cocco M (1996) Frictional constraints on crustal faulting. J Geophys Res 101:13895-13909

Coffin MF, Gahagan LM, Lawver LA (1998) Present-day plate boundary digital data compilation, vol 174. Univ of Texas Institute for Geophys Tech Rep, p 5

Dieterich JH (1979) Modeling of rock friction: 1. Experimental results and constitutive equations. J Geophys Res 84:2161-2168

Furumura T, Imai K, Maeda T (2011) A revised tsunami source model for the 1707 Hoei earthquake and simulation of tsunami inundation of Ryujin Lake, Kyushu. Jpn J Geophys Res 116:B02308. doi:10.1029/2010JB007918

Hasegawa A, Yoshida K, Okada T (2011) Nearly complete stress drop in the 2011 Mw9.0 off the Pacific coast of Tohoku Earthquake. Earth Planets Space 63(7):703-707. doi:10.5047/eps.2011.06. 007

Hyodo M, Hori T (2010) Modeling of Nankai earthquake cycles: influence of 3D geometry of the Philippine Sea plate on seismic cycles. JAMSTEC Rep Dev 11:1-15 (written in Japanese with English abstract and figure captions)

Ide S, Beroza GC, Shelly DR, Uchide T (2007) A new scaling law for slow earthquakes. Nature 447:76-79. doi:10.1038/nature05780

Ikari MJ, Saffer DM (2012) Permeability contrasts between sheared and normally consolidated sediments in the Nankai accretionary prism. Mar Geol 295-298:1-13. doi:10.1016/j.margeo.2011.11. 006

Ikari MJ, Marone C, Saffer DM, Kopf AJ (2013) Slip weakening as a mechanism for slow earthquakes. Nat Geosci 6:468-472. doi:10. 1038/ngeo1818

Inazu D, Hino R (2011) Temperature correction and usefulness of ocean bottom pressure data from cabled seafloor observatories around Japan for analyses of tsunamis, ocean tides, and lowfrequency geophysical phenomena. Earth Planets Space 63: 1133-1149. doi:10.5047/eps.2011.07.014

Ishibashi K (1981) Specification of a soon-to-occur seismic faulting in the Tokai district, central Japan, based upon seismotectonics. In: Simpson DW, Richards PG (eds) Earthquake prediction-an international review, maurice ewing series, vol 4, AGU, Washington, DC, pp 297-332

Ishibashi K (1999) Great Tokai and Nankai, Japan, earthquakes as revealed by historical seismology: 1 . Review of the Events until mid-14th century. J Geogr 108(4):399-423 (written in Japanese with English abstract)

Ito Y, Obara K (2006) Dynamic deformation of the accretionary prism excites very low frequency earthquakes. Geophys Res Lett 33:L02311. doi:10.1029/2005GL025270

Ito T, Yoshioka S, Miyazaki S (1999) Interplate coupling in southwest Japan deduced from inversion analysis of GPS data. Phys Earth Planet Inter 115:17-34

Ito Y, Obara K, Shiomi K, Sekinie S, Hirose H (2007) Slow earthquakes coincident with episodic tremors and slow slip events. Science 315:503-506. doi:10.1126/science.1134454

Ito Y, Hino R, Kido M, Fujimoto H, Osada Y, Inazu D, Ohta Y, Iinuma T, Ohzono M, Miura S, Mishina M, Suzuki K, Tsuji T, Ashi J (2013) Episodic slow slip events in the Japan subduction zone before the 2011 Tohoku-Oki earthquake. Tectonophysics. doi: $10.1016 /$ j.tecto.2012.08.022 (in press)

Kanamori H (1972) Tectonic implications of the 1944 Tonankai and the 1946 Nankaido earthquakes. Phys Earth Planet Inter 5:129-139

Kanamori H (1977) The energe release in great earthquakes. J Geophys Res 82(20):2981-2987

Kaneda Y, Kawaguchi K, Araki E, Sakuma A, Matsumoto H, Nakamura T, Kamiya S, Ariyoshi K, Baba T, Ohori M, Hori T (2009) Dense Ocean floor Network for Earthquakes and Tsunamis (DONET) - development and data application for the mega thrust earthquakes around the Nankai trough. Eos Trans AGU 90(52): Fall Meet Suppl Abstract S53A-1453

Katayama I, Terada T, Okazaki K, Tanikawa W (2012) Episodic tremor and slow slip potentially linked to permeability contrast at the Moho. Nat Geosci 5:731-734. doi:10.1038/NGEO1559

Kato N, Hirasawa T (1999) A model for possible crustal deformation prior to a coming large interplate earthquake in the Tokai distinct, Central Japan. Bull Seism Soc Am 89:1401-1417

Kato A, Iidaka T, Ikuta R, Yoshida Y, Katsumata K, Iwasaki T, Sakai S, Thurber C, Tsumura N, Yamaoka K, Watanabe T, Kunitomo T, Yamazaki F, Okubo M, Suzuki S, Hirata N (2010) Variations of fluid pressure within the subducting oceanic crust and slow earthquakes. Geophys Res Lett 37:L14310. doi:10.1029/ 2010GL043723

Kato A, Obara K, Igarashi T, Tsuruoka H, Nakagawa S, Hirata N (2012) Propagation of slow slip leading up to the $2011 \mathrm{Mw} 9.0$ Tohoku-Oki earthquake. Science 335(6069):705-708. doi:10. 1126/science. 1215141 
Kido M, Fujimoto H, Miura S, Osada Y, Tsuka K, Tabei T (2006) Seafloor displacement at Kumano-nada caused by the 2004 off Kii Peninsula earthquake, detected through repeated GPS/ acoustic surveys. Earth Planets Space 58:911-915

Kikuchi M, Nakamura M, Yoshikawa K (2003) Source rupture processes of the 1944 Tonankai earthquake and the 1945 Mikawa earthquake derived from low-gain seismograms. Earth Planets Space 55:159-172

Lay T, Kanamori H, Ammon CJ, Nettles M, Ward SN, Aster RC, Beck SL, Bilek SL, Brudzinski MR, Butler R, DeShon HR, Ekström G, Satake K, Sipkin S (2005) The great SumatraAndaman earthquake of 26 December 2004. Science 308:1127-1133. doi:10.1126/science. 1112250

Liu Y, Rice JR (2005) Aseismic slip transients emerge spontaneously in three-dimensional rate and state modeling of subduction earthquake sequences. J Geophys Res 110:B08307. doi:10.1029/ 2004JB003424

Maccaferri F, Rivalta E, Passarelli L, Jonsson S (2013) The stress shadow induced by the 1975-1984 Krafla rifting episode. J Geophys Res 118:1109-1121. doi:10.1002/jgrb.50134

Matsuzawa T, Hirose H, Shibazaki B, Obara K (2010) Modeling short- and long-term slow slip events in the seismic cycles of large subduction earthquakes. J Geophys Res 115(B12): B12301. doi:10.1029/2010JB007566

Miyazaki S, Heki K (2001) Crustal velocity field of southwest Japan: subduction and arc-arc collision. J Geophys Res 106:4305-4326. doi:10.1029/2000JB900312

Müller RD, Sdrolias M, Gaina C, Roest WR (2008) Age, spreading rates, and spreading asymmetry of the world's ocean crust. Geochem Geophys Geosyst 9(4):Q04006. doi:10.1029/2007GC001743

Nakanishi A, Kodaira S, Miura S, Ito A, Sato T, Park JO, Kido Y, Kaneda Y (2008) Detailed structural image around splay-fault branching in the Nankai subduction seismogenic zone: results from a high-density ocean bottom seismic survey. J Geophys Res 113:B03105

Nakano M, Nakamura T, Kamiya S, Ohori M, Kaneda Y (2013a) Intensive seismic activity around the Nankai trough revealed by DONET ocean-floor seismic observations. Earth Planets Space 65(1):5-15. doi:10.5047/eps.2012.05.013

Nakano M, Nakamura T, Kamiya S, Kaneda Y (2013b) Seismic activity beneath the Nankai trough revealed by DONET oceanbottom observations. doi:10.1007/s11001-013-9195-3

Obara K (2010) Phenomenology of deep slow earthquake family in southwest Japan: spatiotemporal characteristics and segmentation. J Geophys Res 115:B00A25. doi:10.1029/2008JB006048

Obara K, Sekine S (2009) Characteristic activity and migration of episodic tremor and slow-slip events in central Japan. Earth Planets Space 61:853-862
Okada Y (1992) Internal deformation due to shear and tensile faults in a halfspace. Bull Seism Soc Am 82:1018-1040

Ozawa S, Nishimura T, Suito H, Kobayashi T, Tobita M, Imakiire T (2011) Coseismic and postseismic slip of the 2011 magnitude-9 Tohoku-Oki earthquake. Nature 475:373-376. doi:10.1038/ nature 10227

Polster A, Fabian M, Villinger H (2009) Effective resolution and drift of paroscientific pressure sensors derived from long-term seafloor measurements. Geochem Geophys Geosyst 10:Q08008. doi:10. 1029/2009GC002532

Rice JR (1993) Spatio-temporal complexity of slip on a fault. J Geophys Res 98:9885-9907

Rubin AM, Ampuero JP (2005) Earthquake nucleation on (aging) rate and state faults. J Geophys Res 110:B11312. doi:10.1029/ 2005JB003686

Ruina A (1983) Slip instability and state variable friction laws. J Geophys Res 88:10359-10370

Savage JC (1983) A dislocation model of strain accumulation and release at a subduction zone. J Geophys Res 88:4984-4996

Schwartz SY, Rokosky JM (2007) Slow slip events and seismic tremor at circum-Pacific subduction zones. Rev Geophys 45:RC3004. doi:10.1029/2006RG000208

Segall P (2010) Earthquake and volcano deformation. Princeton Univ. press, Oxford

Sella GF, Dixon TH, Mao A (2002) REVEL: a model for recent plate velocities from space geodesy. J Geophys Res 107(B4):2081. doi:10.1029/2000JB000033

Shibazaki B, Obara K, Matsuzawa T, Hirose H (2012) Modeling of slow slip events along the deep subduction zone in the Kii Peninsula and Tokai regions, southwest Japan. J Geophys Res 117(B6):B06311. doi:10.1029/2011JB009083

Sugioka H, Okamoto T, Nakamura T, Ishihara Y, Ito A, Obana K, Kinoshita M, Nakahigashi K, Shinohara M, Fukao Y (2012) Tsunamigenic potential of the shallow subduction plate boundary inferred from slow seismic slip. Nat Geosci 5:414-418. doi:10.1038/NGEO1466

Tamura Y, Sato T, Ooe M, Ishiguro M (1991) A procedure for tidal analysis with a Bayesian information criterion. Geophys J Int 104:507-516

The Headquarters for Earthquake Research Promotion (2013) Evaluations of occurrence potentials or subduction-zone earthquakes to date (written in Japanese). http://www.jishin.go.jp/main/p_ hyoka02_kaiko.htm

Wessel P, Smith WHF (1998) New, improved version of the generic mapping tools released. Eos Trans AGU 79:579

Yagi Y, Fukahata Y (2011) Rupture process of the 2011 Tohoku-oki earthquake and absolute elastic strain release. Geophys Res Lett 38:L19307. doi:10.1029/2011GL048701 